\title{
ON THE STRUCTURE OF MORTALITY AMONG THE REGIONS IN THE SLOVAK REPUBLIC
}

\author{
Matúš Kubák ${ }^{1}$, Beáta Gavurová1, Peter Jarčuška², Martin Janičko² \\ ${ }^{1}$ Faculty of Economics, Technical University of Košice, Košice, Slovak Republic \\ ${ }^{21 s t ~ D e p a r t m e n t ~ o f ~ I n t e r n a l ~ M e d i c i n e, ~ U n i v e r s i t y ~ H o s p i t a l ~ a n d ~ F a c u l t y ~ o f ~ M e d i c i n e ~ P a v o l ~ J o z e f ~ S ̌ a f a ́ r i k ~ U n i v e r s i t y ~ i n ~ K o s ̌ i c e, ~ K o s ̌ i c e, ~ S l o v a k ~}$ \\ Republic
}

\section{SUMMARY}

Aim: The Slovak Republic consists of eight regions which may dispose a different structure of cause-specific mortality. The aim of this study is to reveal the regions with higher risk of dying from the main categories of diseases selected according to the chapters of the International Classification of Diseases (ICD-10).

Methods: Data were obtained from mortality reports throughout 1996-2014. We applied multinomial logistic regression analysis, where the dependent variable is death categories and the explanatory variables are regions, age, year and gender. The Bratislava region and Diseases of the circulatory system are set as the reference level.

Results: We propose a spatiotemporal analysis of the relative risk ratio of dying in the Slovak Republic for every significant group of diseases from the International Statistical Classification of Diseases and Related Health Problems maintained by the World Health Organization. Moreover, we propose gender and age analysis.

Conclusions: These results could be useful for setting active prevention programs, as well as a hospital network specialising in high risk diagnoses in Slovakian regions.

Key words: cause-specific mortality, regional differences, multinomial logistic regression analysis, relative risk ratios

Address for correspondence: M. Janičko, 1st Department of Internal Medicine, University Hospital and Faculty of Medicine Pavol Jozef Šafárik University in Košice, Trieda SNP 1, 04011 Košice, Slovak Republic. E-mail: martin.janicko@gmail.com

https://doi.org/10.21101/cejph.a4957

\section{INTRODUCTION}

Mortality is one of the main indicators reflecting the effectiveness of the health care system in each country. According to many authors (1-5) mortality offers a reliable picture of public health, as well as the most objective way of measuring health. Changes in demographic trends are also reflected in changes in morbidity and mortality of the population. Causality between these components is the subject of many research studies (6-12). Over the past three decades, the most numerous diseases and causes of death shifted from infectious to a group of chronic diseases (13-19).

Slovakia has a disposable database for the analysis of mortality, however they are absent research studies mapping the development of mortality according to individual diagnoses in detail. Variability of mortality development by years shows that the evolution of mortality should be also examined in terms of regional differences. Through the mapping of regional disparities in the development of mortality can be effectively adjusted prevention programs and other interventions which could be useful for the control of mortality in different regions.

The aim of this study is to reveal possible existing differences in mortality trends among regions of Slovak Republic by the relative risk ratios. Table 1 depicts the distribution of causes of deaths in Slovak Republic according to International Statistical Classification of Diseases and Related Health Problems maintained by the World Health Organization. Our cohort study contains all dead persons in Slovak Republic within period from 1996 to 2014. In total, we have 997,165 observations (dead persons). Table 1 tells us, that main causes of deaths in the Slovak Republic are diseases of the circulatory system, neoplasms, diseases of the respiratory system, injury, poisoning and certain other consequences of external causes, and diseases of the digestive system.

\section{MATERIALS AND METHODS}

We use multinomial logistic regression, which is applicable in cases, when the dependent variable is nominal with more than two levels. Multinomial logistic regression is thus extension of logistic regression, which is applicable when the response variable is binary (dichotomous). Multinomial logistic regression does not assume normality, linearity and homoscedasticity. Analysis was done by IBM SPSS Software.

As mentioned above, in our analysis we are interested in differences in mortality across Slovak Republic. In our regression, response variable (dependent variable) is death category, according the International Statistical Classification and Related Health Problems. Pursuant to the above, we have 19 categories of the response variable. Our explanatory variables are Region, Gender, Year and Age. Region and Gender are qualitative variables, 


\begin{tabular}{|c|c|c|c|c|c|c|c|c|c|c|c|c|c|c|c|c|c|c|c|}
\hline 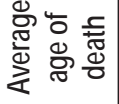 & 8 & $\hat{0}$ & 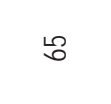 & $\therefore$ & 8 & $\stackrel{\infty}{\circ}$ & 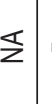 & أ & : & న & $3 \therefore$ & 岂 & $\mathbb{N}$ & $\vec{m}$ & 0 & $\infty$ & 吕 & 요 & 1 \\
\hline$\therefore$ & 足 & & ") & $\underset{-}{\stackrel{i}{i}}$ & $\because$ & $\stackrel{\sim}{\Im}$ & : & $\stackrel{0}{\circ}$ & 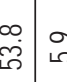 & \begin{tabular}{l|ll}
$\stackrel{9}{\circ}$ & $\vec{n}$
\end{tabular} & $\begin{array}{l}\dot{0} \\
\vdots\end{array}$ & -1) & $\stackrel{\nabla}{-}$ & $\because$ & $\stackrel{m}{0}$ & $\stackrel{m}{0}$ & $\stackrel{\text { O }}{\mathrm{i}}$ & 함 & $\begin{array}{l}0 \\
\stackrel{0}{0} \\
0\end{array}$ \\
\hline 颉 & 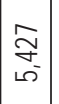 & 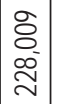 & $\underset{-}{\vec{\rho}}$ & 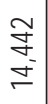 & $\stackrel{m}{m}$ & $\begin{array}{l}\mathcal{F} \\
\stackrel{G}{G} \\
\exists\end{array}$ & 0 & $\sigma \mid$ & 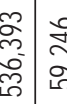 & 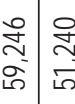 & \begin{tabular}{l|l}
0 \\
$\vdots$ \\
$\vdots$
\end{tabular} & 只 & 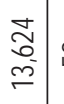 & i & $\underset{\sim}{\stackrel{2}{\sim}}$ & $\begin{array}{l}\text { P } \\
\text { i } \\
\text { i }\end{array}$ & 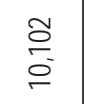 & 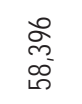 & 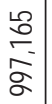 \\
\hline 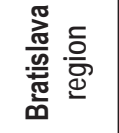 & 离 & $\mid \begin{array}{c}\hat{\tilde{O}} \\
\stackrel{\sim}{\sim} \\
\sim\end{array}$ & $\stackrel{\dddot{9}}{\rightarrow}$ & 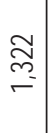 & in & $\begin{array}{l}\stackrel{\mathrm{S}}{\rightarrow-} \\
-\end{array}$ & 0 & 0 & 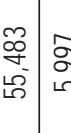 & 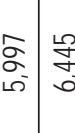 & $\begin{array}{l}0 \\
\frac{p}{5} \\
5\end{array}$ & 。্ণ & $\begin{array}{l}\widetilde{N} \\
\widetilde{-} \\
\widetilde{-}\end{array}$ & $\nabla$ & ్ָ & $\stackrel{\leftrightarrow}{\rightarrow}$ & $\stackrel{g}{\stackrel{9}{7}}$ & 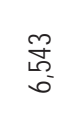 & 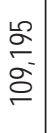 \\
\hline 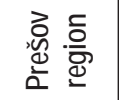 & 总 & $\mid \begin{array}{c}0 \\
\stackrel{0}{\sim} \\
\stackrel{\sim}{\sim}\end{array}$ & $\stackrel{\widetilde{g}}{\rightarrow}$ & 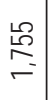 & $\approx$ & 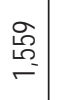 & 0 & $\nabla$ & 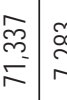 & 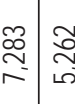 & $\begin{array}{c}\qquad \\
\vdots \\
5\end{array}$ & 虽 & $\begin{array}{l}\text { 管 } \\
\text { - }\end{array}$ & 으 & $\vec{\sim}$ & প্ల & $\underset{-i}{\stackrel{o}{g}}$ & 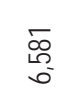 & 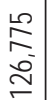 \\
\hline 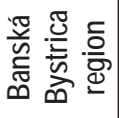 & هి & $\mid$ & 总 & 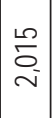 & $\stackrel{\sim}{\sim}$ & 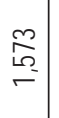 & 0 & 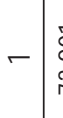 & 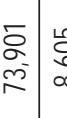 & 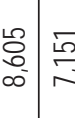 & $=7$ & $\stackrel{\mathscr{্}}{\oplus}$ & $\underset{\substack{\sim \\
\sim}}{\sim}$ & $\infty$ & 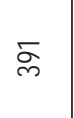 & $\stackrel{\infty}{\text { 岗 }}$ & 孛 & 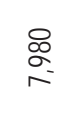 & 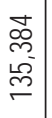 \\
\hline 茎高 & 总 & 兽 & $\vec{G}$ & 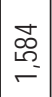 & 户े & $\begin{array}{l}\infty \\
\stackrel{m}{-} \\
\rightarrow\end{array}$ & 0 & 0 & 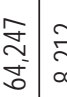 & 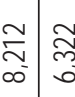 & $\begin{array}{l}y_{1} \\
\vdots \\
\vdots\end{array}$ & 8 & $\begin{array}{c}\mathcal{O} \\
\underset{-}{*}\end{array}$ & $m$ & ஜ్ల & $\underset{m}{\mathbb{d}}$ & $\underset{\sim}{\stackrel{\infty}{\sigma}}$ & $\begin{array}{l}\text { ? } \\
\text { O- } \\
\infty^{\circ}\end{array}$ & 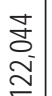 \\
\hline 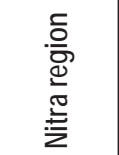 & $\stackrel{\infty}{\circ}$ & $\mid \begin{array}{l}0 \\
0 \\
\text { s. } \\
\text { s. }\end{array}$ & 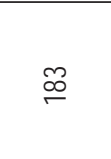 & 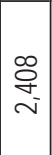 & $f$ & $\begin{array}{l}\text { 号 } \\
\stackrel{-}{-}\end{array}$ & 0 & $\rightarrow$ & 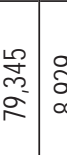 & 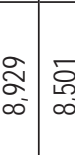 & 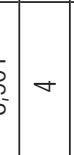 & 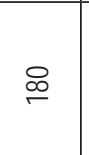 & 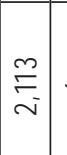 & 0 & 营 & స్ల & $\underset{-}{\vec{J}}$ & $\begin{array}{l}\text { 吕 } \\
\text { o }^{\circ}\end{array}$ & 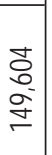 \\
\hline 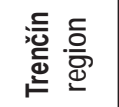 & ర్ & 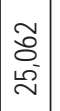 & প্ল & $\mid \begin{array}{l}\stackrel{L}{0} \\
\stackrel{-}{-} \\
\rightarrow-1\end{array}$ & 아 & $\underset{\vec{\sigma}}{\vec{\sigma}}$ & 0 & 0 & 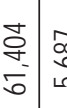 & 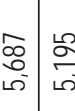 & $\begin{array}{l}\frac{3}{4} \\
\frac{1}{5}\end{array}$ & $\stackrel{\circ}{\infty}$ & $\left|\begin{array}{c}\mathbb{8} \\
\stackrel{9}{-} \\
\rightarrow\end{array}\right|$ & مـ & $\stackrel{\mathscr{N}}{\sim}$ & $\stackrel{g}{\sim}$ & $\underset{-}{\stackrel{0}{二}}$ & 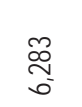 & $\begin{array}{l}\stackrel{g}{9} \\
\text { o. } \\
\stackrel{9}{9}\end{array}$ \\
\hline 䙔 & $\stackrel{\mathscr{m}}{\sim}$ & 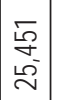 & I & $\begin{array}{c}\stackrel{8}{8} \\
\stackrel{m}{-}\end{array}$ & 용 & 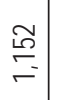 & 0 & 0 & 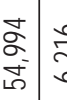 & 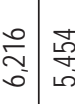 & $\begin{array}{lll}0 \\
\vdots \\
5\end{array}$ & $\stackrel{\Omega}{2}$ & 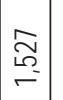 & $\Rightarrow$ & 芩 & $\stackrel{\vec{N}}{\vec{N}}$ & $\stackrel{\infty}{\sim}$ & 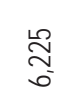 & $\begin{array}{l}\text { 导 } \\
\text { 吾 }\end{array}$ \\
\hline 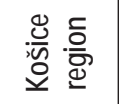 & $\underset{\sim}{\sim}$ & 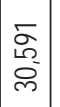 & 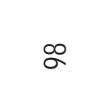 & 总 & $\stackrel{\sim}{\sim}$ & 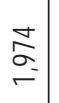 & 0 & $m$ & 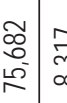 & \begin{tabular}{c|c}
$\vec{c}$ & \multicolumn{2}{c}{} \\
$\infty^{\circ}$ & $\bar{g}$
\end{tabular} & $\begin{array}{l}b_{1} \\
\\
b\end{array}$ & $\widetilde{\widetilde{g}}$ & $\mid$ & $\cong$ & 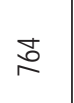 & 吕 & 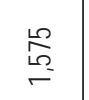 & 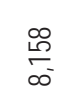 & 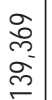 \\
\hline 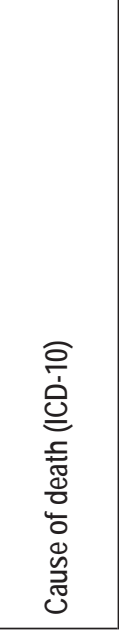 & 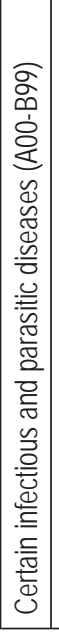 & 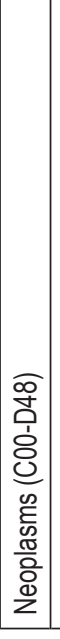 & 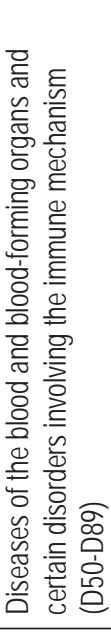 & 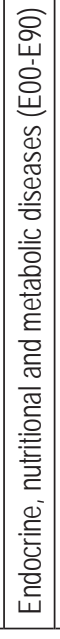 & 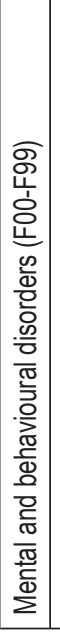 & 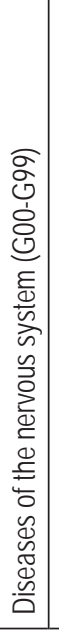 & 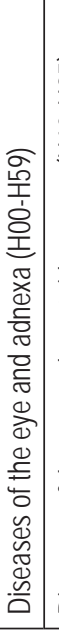 & 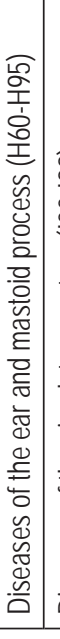 & 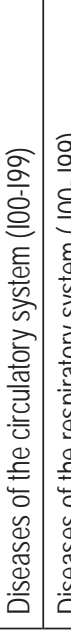 & 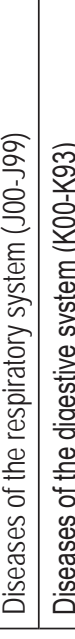 & 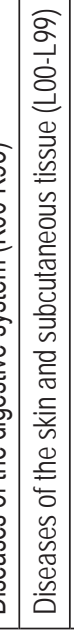 & 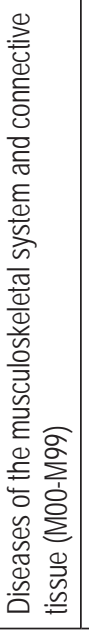 & 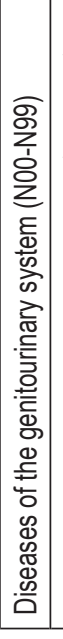 & 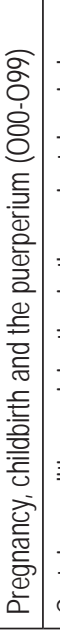 & 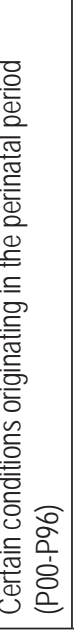 & 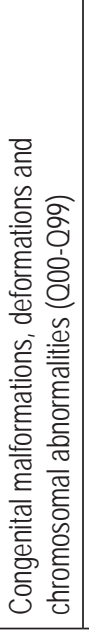 & 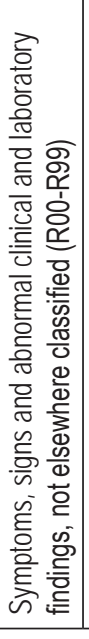 & 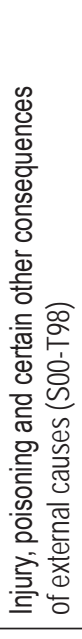 & 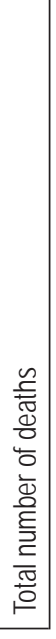 \\
\hline
\end{tabular}


whilst Year and Age are continuous varibles. In case of qualitative explanatory variable, we refer to a factor. In our multinomial logistic regression we use Diseases of the circulatory system as a reference category. We are doing so, because it is usual practice in cases, when sample sizes are very unequal in the groups what is our case. This occurs often for naturally occurring groups, what the mortality undoubtedly is. As the reference level, Bratislava region was set. We do so mainly because of the fact, that Bratislava region significantly outperform other regions of the Slovak Republic in terms of economic activity (Bratislava region is in top 10 economically strongest regions in EU and attaint over $80 \%$ of the EU-28 average in gross value added per person employed) (20). Moreover, capital city of the Slovak Republic, Bratislava, is situated in Bratislava region and regions with capital cities usually operate under different modes as the rest of the country. The distribution of the population of Slovak Republic within regions is following: Bratislava region: 633,288 residents; Košice region: 796,650; Trnava region: 559,697; Trenčín region: 589,935; Nitra region: 682,527; Žilina region: 690,434; Banská Bystrica region: 653,024; Prešov region: 820,697. This distribution of residents is also argument for using Bratislava region as reference level, because this region is medially populated to other regions.

Model fit is significant, which indicates that full model predicts significantly better, or more accurately, than the null model.

\section{RESULTS}

In following subheads the analyses for every group of diseases are presented. We gave up the analysis of Diseases of the eye and adnexa (H00-H59), Diseases of the ear and mastoid process (H60-H95), Diseases of the skin and subcutaneous tissue (L00-L99), Pregnancy, childbirth and the puerperium (O00-O99) where number of deaths is too low and this fact would result in an instability of our model. Results of multinomial logistic regression are shown in Table 2 and in Table 3.

Just 5,427 people died, thus $0.5 \%$ of the total death number has been caused by Certain infectious and parasitic diseases (Table 1). As we can see in Table 2, the relative risk of dying for reasons of Certain infectious and parasitic diseases is 35\% lower in the Košice region than in Bratislava region relative to Diseases of the circulatory system. This chance is likewise lower in all other regions: in Trnava region lower by $28 \%$, in Trenčín region lower by $31 \%$, in the Nitra region lower by $42 \%$, in Žilina region by $12 \%$, in Banská Bystrica region by $10 \%$ and in Prešov region by $41 \%$. Males are by $16 \%$ less likely to die because of Certain infectious and parasitic diseases than females. Age has negative influence on risk of dying because of Certain infectious and parasitic diseases relative to Diseases of the circulatory system. So as age increase by one year, the risk of dying because of Certain infectious and parasitic diseases as compared to Diseases of the circulatory system diminish by $6 \%$. Over time, the risk of dying because of Certain infectious and parasitic diseases as compared to Diseases of the circulatory system has increased by $9 \%$ (Table 2).

Neoplasms were as a cause of death detected in 228,009, what is $22.9 \%$ of all deaths. Since all regression coefficients concerning region are less than 1 , the relative risk of dying due to neoplasms is smaller than in Bratislava region relative to diseases of the circulatory system in all regions. This chance is by $27 \%$ lower in Košice region, only by $11 \%$ lower in Trnava region, by $21 \%$ lower in Trenčín region, by $13 \%$ lower in Nitra region, by $20 \%$ lower in Žilina region, by $26 \%$ lower in Banská Bystrica region and by $19 \%$ lower in the Prešov region; comparing to Bratislava region. Males are by $18 \%$ more likely to die because of Neoplasms than females relative to Diseases of the circulatory system. As age increase by one year, the risk of dying because of Neoplasms decrease by $5 \%$ relative to Diseases of the circulatory system. Within time span from 1996 to 2014, the risk of dying because of Neoplasms as compared to Diseases of the circulatory system has increased by $1.9 \%$ (Table 2 ).

Only 1,031 persons died because of the diagnosis, which are included in chapter of Diseases of the blood and blood-forming organs and certain disorders involving the immune mechanism. Here the relative risk of death because of Diseases of the blood and blood-forming organs and certain disorders involving the immune mechanism are smaller in the Košice region by 51\%, in Banská Bystrica region by $43 \%$ and in the Prešov region by $28 \%$ than in Bratislava region versus Diseases of the circulatory system. Males are less likely to die because of Diseases of the blood and blood-forming organs and certain disorders involving the immune mechanism than females relative to Diseases of the circulatory system by $37 \%$. With age, the risk of dying because of Diseases of the blood and blood-forming organs and certain disorders involving the immune mechanism decrease by $6 \%$ relative to Diseases of the circulatory system. Within period 1996-2014, the risk of dying because of Diseases of the blood and blood-forming organs and certain disorders involving the immune mechanism as compared to Diseases of the circulatory system has increased by $2.8 \%$ (Table 2).

During observed period 14,442 persons died because of diseases which are included in Endocrine, nutritional and metabolic diseases group. Contrary to our previous results, the relative risk of dying for reasons of Endocrine, nutritional and metabolic diseases is by $21 \%$ higher in Košice region, by $14 \%$ higher in Trenčín region, by $25 \%$ higher in Nitra region and by $11 \%$ higher in the Banská Bystrica region than in Bratislava region relative to Diseases of the circulatory system. Males are by 31\% less likely to die because of Endocrine, nutritional and metabolic diseases than females relative to Diseases of the circulatory system. As age increase by one year, the risk of dying because of Endocrine, nutritional and metabolic diseases decrease by $3 \%$ relative to Diseases of the circulatory system. Over time, the risk of dying because of Endocrine, nutritional and metabolic diseases as compared to Diseases of the circulatory system has increased by $0.4 \%$ (Table 2).

Mental and behavioural disorders occur as a cause of death very occasionally, only in 313 cases per examined period. The odds of demise because of mental and behavioural disorders are smaller in the Košice region by $71 \%$, in Trenčín region by $39 \%$, in Nitra region by $44 \%$, in Žilina region by $54 \%$, in Banská Bystrica region by $66 \%$ and in Prešov region by $74 \%$ than in Bratislava region compared to Diseases of the circulatory system. In case of Trnava region and Age the coefficients is not statistically significant. Age has negative influence on risk of dying because of Mental and behavioural disorders relative to Diseases of the circulatory system. So as age increase by one year, the risk of dying because of Mental and behavioural disorders as compared to Diseases of the circulatory system diminish by $7 \%$. Over time, 


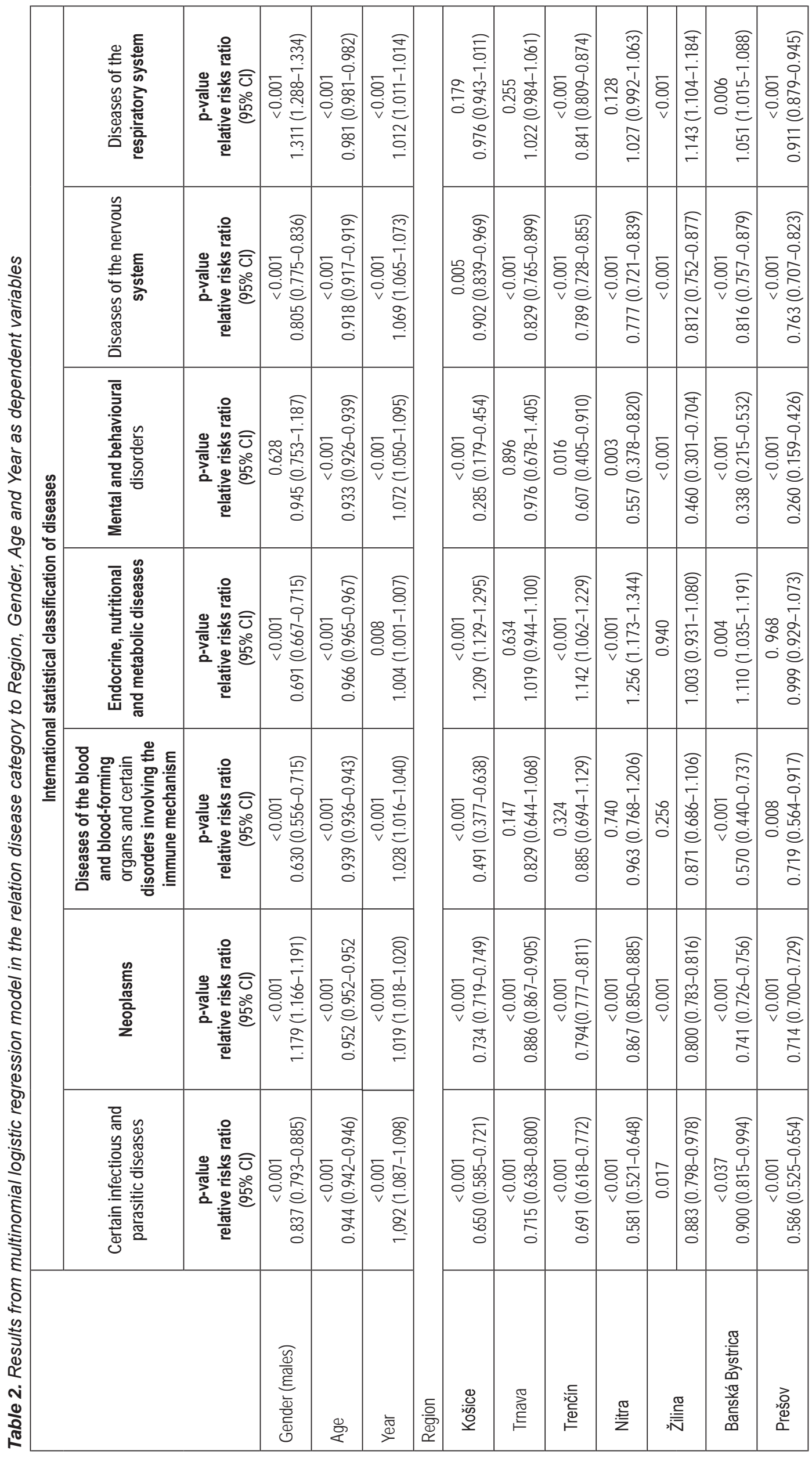


the risk of dying because of Mental and behavioural disorders as compared to Diseases of the circulatory system has increased by $7 \%$ (Table 2 ).

Diseases of the Nervous system caused death in 11,642 cases, what equals to $1.2 \%$ of all deaths. The relative risk of dying because of Diseases of the nervous system is smaller in Košice region by $10 \%$, in Trnava region by $17 \%$, in Trenčín region by $21 \%$, in Nitra region by $22 \%$, in Žilina region by $19 \%$, in Banská Bystrica region by $18 \%$ and in Prešov region by $24 \%$ by comparing to Bratislava region and relative to Diseases of the circulatory system. Males are by $19 \%$ less likely to die because of Diseases of the nervous than females relative to Diseases of the circulatory system. With increasing age, the risk of dying because of Diseases of the nervous decrease by $8 \%$ relative to Diseases of the circulatory system. Within time span from 1996 to 2014, the risk of dying because of Diseases of the nervous as compared to Diseases of the circulatory system has increased by 7\% (Table 2).

Diseases of the respiratory system caused death in 59,246 cases, what is $5.9 \%$ of all deaths. In group of diseases belonging to Diseases of the respiratory system we observe two patterns. There are two types of regions. Among the regions where the relative probability of dying for reasons of Diseases of the respiratory system relative to Diseases of the circulatory system is lower than in Bratislava region, regions of Trenčín and Prešov belong. This chance is lower in Trenčín region by $16 \%$ comparing to Bratislava region and by $9 \%$ in Prešov region. On the other hand, we distinguish two regions where the risk of dying due to Diseases of the respiratory system relative to Diseases of the circulatory system are higher than in Bratislava region. These regions are Nitra region, where the risk of dying due to Diseases of the respiratory system relative to Diseases of the circulatory system is higher by $2.7 \%$ than in Bratislava region and Žilina region, where the risk is higher by $14 \%$. Males are by $31 \%$ more likely to die because of Diseases of the respiratory system than females relative to Diseases of the circulatory system. By aging, the risk of dying because of Diseases of the respiratory system diminish by $2 \%$ relative to Diseases of the circulatory system. Within the observed period, the risk of dying because of Diseases of the respiratory system as compared to Diseases of the circulatory system has increased by $1 \%$ (Table 2 ).

Diseases of the digestive system caused 51,240 deaths what equals to $5.1 \%$ of all deaths. Table 3 indicates, that in cluster of Diseases of the digestive system we have similar pattern which prevails in the majority of other clusters. The risk of demise caused by Diseases of the digestive system are lower in all regions of the Slovak Republic than in Bratislava region relative to Diseases of the circulatory system. This chance is minor in the Košice region by $33 \%$, in Trnava region by $20 \%$, in Trenčín region by $31 \%$, in Nitra region by $11 \%$, in Žilina region by $24 \%$, in Banská Bystrica by $24 \%$ and in Prešov region even by $45 \%$. Males are more likely to die because of Diseases of the digestive system relative to Diseases of the circulatory system by $25 \%$. With age, the risk of dying because of Diseases of the digestive system decrease by $6 \%$ relative to Diseases of the circulatory system. Over time, the risk of dying because of Diseases of the digestive system as compared to Diseases of the circulatory system has increased by $2.7 \%$ (Table 3 ).

Diseases of the musculoskeletal system and connective tissue occur as a cause of death rarely, in only 935 cases. The risk of demise because of Diseases of the musculoskeletal system and connective tissue is smaller in Trnava region by $29 \%$, in Trenčín region by $25 \%$ and in Žilina region by $45 \%$ than in Bratislava region and relative to Diseases of the circulatory system. Coefficients for other regions are not statistically significant. Concerning generic differences, we observe that males are by $65 \%$ less prone to die because of Diseases of the musculoskeletal system and connective tissue relative to Diseases of the circulatory system by $25 \%$ than females are. With age, the risk of dying because of Diseases of the musculoskeletal system and connective tissue decrease by $6 \%$ relative to Diseases of the circulatory system. Over time, the risk of dying because of Diseases of the musculoskeletal system and connective tissue as compared to Diseases of the circulatory system has increased by 2.6\% (Table 3).

Diseases of the genitourinary system caused death in 13,624 cases. In this category of diseases the relative risk of dying for reasons of Diseases of the genitourinary system is lower in the Košice region by $43 \%$, in Trnava region by $22 \%$, in Trenčín region by $37 \%$, in Nitra region by $25 \%$, in Žilina region by $38 \%$, in Banská Bystrica region by $20 \%$ and in Prešov region by $40 \%$ compared to Bratislava region and relative to Diseases of the circulatory system. In case of Diseases of the genitourinary system, males are by $10 \%$ less likely to die than females relative to Diseases of the circulatory system. By aging, the risk of dying because of Diseases of the nervous decrease by 3\% relative to Diseases of the circulatory system. Within the observed period, the risk of dying because of Diseases of the genitourinary system as compared to Diseases of the circulatory system has increased by $0.6 \%$ (Table 3 ).

Certain conditions originating in the perinatal period are concerning fetuses and newborns. We count here 3,275 deaths. The interpretation of obtained coefficients is here a little bit strange, as this cluster is different from others in terms, that already living individuals can not have as a cause of death diagnose from this cluster. Anyway, we will interpret the coefficients about generic differences and time aspect, but keep in mind about stated fact. Males are by $65 \%$ more likely to die because of Certain conditions originating in the perinatal period than females. Over time, the risk of dying because of Certain conditions originating in the perinatal period compared to Diseases of the circulatory system has increased by $1.5 \%$ (Table 3 ).

2,970 deaths occurred in observed period in Congenital malformations, deformations and chromosomal abnormalities group of deseases. The relative risk of dying because of Congenital malformations, deformations and chromosomal abnormalities is by $46 \%$ smaller in Košice region and by $28 \%$ smaller in Prešov region compared to Bratislava region and relative to Diseases of the circulatory system. Females are by $8 \%$ less likely to die because of Congenital malformations, deformations and chromosomal abnormalities than males relative to Diseases of the circulatory system. As age increase by one year, the risk of dying because of Congenital malformations, deformations and chromosomal abnormalities as compared to Diseases of the circulatory system diminish by $18 \%$. Over time, the risk of dying because of Congenital malformations, deformations and chromosomal abnormalities as compared to Diseases of the circulatory system has increased by 5.2\% (Table 3).

Exactly 1\% of the population died for the reasons of Symptoms, signs and abnormal clinical and laboratory findings, not elsewhere classified. The relative risk of dying for reasons of Symptoms, 


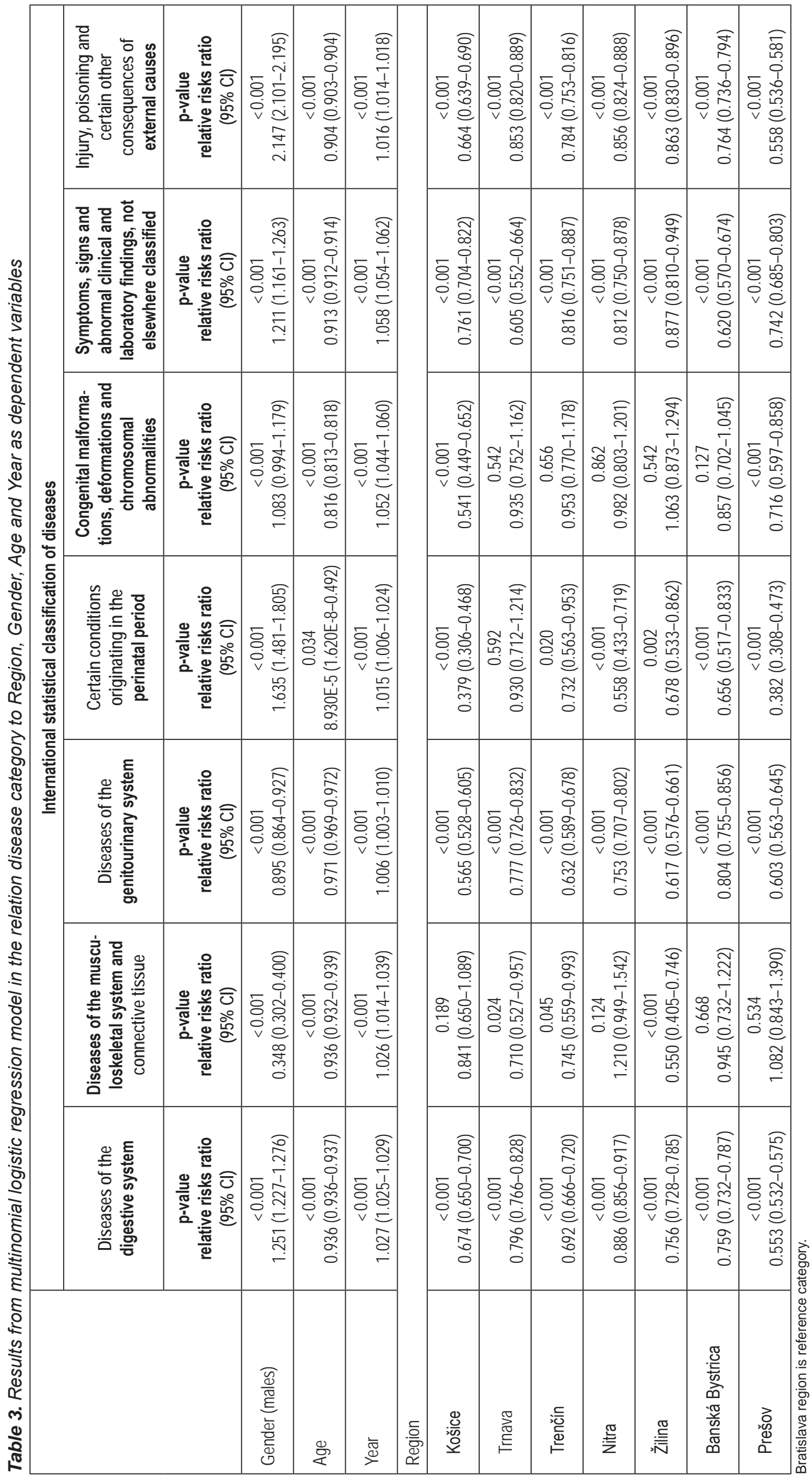


signs and abnormal clinical and laboratory findings, not elsewhere classified is by $24 \%$ lower in Košice region, by $40 \%$ lower in Trnava region, by $18 \%$ lower in Trenčín region, by $19 \%$ lower in Nitra region, by $12 \%$ lower in Žilina region, by $38 \%$ lower in Banská Bystrica region and 26\% lower in Prešov region compared to Bratislava region and relative to Diseases of the circulatory system. Relative risk of dying becase of Symptoms, signs and abnormal clinical and laboratory findings, not elsewhere classified is by $21 \%$ higher in case of males than in case of females relative to Diseases of the circulatory system. By aging, the risk of dying because of Symptoms, signs and abnormal clinical and laboratory findings, not elsewhere classified decrease by $9 \%$ relative to Diseases of the circulatory system. Over time, the risk of dying because of Symptoms, signs and abnormal clinical and laboratory findings, not elsewhere classified as compared to Diseases of the circulatory system has increased by $5.8 \%$ (Table 3 ).

Injuries, poisoning and certain other consequences of external causes contributed to total number of deaths by $6 \%$, what makes 58,396 deaths. Here again, the interpretation of obtained coefficients is a little bit vague, because of coincidence. The relative risk of dying because of Injuries, poisoning and certain other consequences of external causes is by $34 \%$ lower in Košice region, by $15 \%$ lower in the Trnava region, by $22 \%$ lower in the Trenčín region, by $14 \%$ lower in Nitra region, by $14 \%$ lower in Žilina region, by $24 \%$ lower in Banská Bystrica region and by $46 \%$ lower in Prešov region in comparison to Bratislava region and relative to Diseases of the circulatory system. Males are more than twice more likely to die because of Injuries, poisoning and certain other consequences of external causes relative to Diseases of the circulatory system compared to females. With age, the risk of dying because of Injuries, poisoning and certain other consequences of external causes decrease by $10 \%$ relative to Diseases of the circulatory system. Over time, the risk of dying because of Injuries, poisoning and certain other consequences of external causes as compared to Diseases of the circulatory system has increased by $1.6 \%$ (Table 3 ).

\section{DISCUSSION}

Early in the last century, infectious diseases were the most common cause of mortality in the world. The discovery of antibiotics and anti-tuberculotics, major socio-economic changes, and lifestyle modification have changed the structure of mortality over the last 70 years. Diseases of the circulatory system, neoplasms, Diseases of the respiratory system, Injury, poisoning and certain other consequences of external causes and Digestive system diseases are the most frequent causes of death in Slovak republic in the years 1996-2014. The above-mentioned diseases caused the deaths of about 94 percent of the Slovak population, while other diseases have led to death rarely.

Cardiovascular diseases consequenced aproximately 54 percent of all deaths in Slovakia. In Western European countries, cardiovascular morality has a decreasing trend, while in Slovakia it has not declined significantly in the first years of this decade. In addition, standardised mortality ratio for ischemic heart disease in Slovakia is the second highest from all countries of the European Union and is more than 1.5 times higher than in the Czech Republic (21). Genetic predisposition, stress, smoking, consumer lifestyle and civilization diseases (hypertension, diabetes, hyperlipidemia) increase the risk of cardiovascular mortality. Lack of movement, excessive fat intake and inadequate intake of polyunsaturated fatty acids in Slovak males and females accelerate atherogenesis (22). About one quarter of the adult population in Slovakia smokes cigarettes (23). $40 \%$ of young adults in Slovakia suffer from hypertension, the prevalence of hypertension in this age group is one third higher than in Austria or in Hungary. Only a small part of hypertonic patients is regularly managed (24). The prevalence of diabetes in Slovakia is more than $6 \%$ and it has increased in last years (25). $95 \%$ of patients with acute coronary syndrome have at least one of the following risk factors: hypertension, smoking, diabetes mellitus or hyperlipidemia (26).

Changes in the external environment and lifestyle, as well as the prolongation of mean life expectancy, have resulted in increased mortality in oncological diseases in last decades. Incidence and mortality of oncological diseases is higher in both men and women in Slovakia than in the EU. The three most common oncological causes of mortality in Slovakia are lung cancer, colorectal cancer and cancers of the neck and head in the male population and breast cancer, colorectal cancer and lung cancer in the female population (27).

The most common cause of death among digestive diseases in Slovakia is liver cirrhosis. Mortality on liver disease is on the rise in developed countries. Liver disease mortality increased in the United Kingdom between 1970 and 2010 almost six times (28).

Slovakia is at 4th place in men and 5th in women in liver cirrhosis mortality among the European Union countries, although the prevalence of viral hepatitis is not high (29).

Slovakia is one of the countries with the highest consumption of alcohol, alcoholic liver disease is the most common cause of advanced liver diseases in Slovakia.

Our manuscript analyzes the causes of death in Slovakia and its individual regions and the influence of gender and age on causes of mortality. The higher prevalence of cardiovascular morbidity and mortality in rural areas is explained by higher proportion of older population, lower income, unhealthy lifestyle and less accessible specialised cardiology medical care (30). There are large differences in cardiovascular mortality among individual regions in Slovakia. Cardiovascular mortality in the Bratislava region, where more than $85 \%$ of the population lives in the Bratislava urban area, is 50.8\%, while cardiovascular mortality in the Prešov region with the majority of the population living in the rural area is $56.3 \%$. On the other hand, oncological mortality is higher in the Bratislava region than in other Slovak regions.

Although cardiovascular disease is the most common cause of death in the Slovak Republic, the mean age of death is the highest in this group of patients. All other groups of diseases have a shorter life expectancy. The lowest average age of death among the common causes of mortality was in the group Injury, poisoning and certain other consequences of external causes followed by digestive diseases and malignancies. Unhelathy lifestyle shortens life expectancy, many premature deaths in Slovakia are associated with excessive alcohol or tobacco consumption. Smoking reduces the age at the time of a major cardiovascular event, on average, by 10.0 years in men and by 12.4 years in women (26).

Health policy in Slovakia in the coming years must be targeted at reducing cardiovascular morbidity and mortality, early detection 
of malignant diseases and lifestyle improvement including lower consumption of alcohol and tobacco products.

\section{CONCLUSIONS}

Our results can be useful for the setting active prevention programs, as well as a hospital network specialising on the high risky type of diagnosis in the regions of Slovak Republic. Regional differences in mortality are also determined by the limited access to health care which is often the reason of mortality due to the neglect of health care, or the increase of chronic illnesses, what can significantly burden the health care system. By prevention programmes targeted to the selected groups of population as well as the selected regions, the morbidity and mortality can be actively controlled what leads to increasing the effectiveness of health care system.

\section{Acknowledgements}

This work was supported by the VEGA Project No. 1/0945/17 "Research of the economic quantification of marketing processes aimed at increasing the value for the patient, multi-dimensional analyses of the marketing mix of health facilities and quantification of their importance in the process of establishing a system to measure the quality and effectiveness of health system in the Slovak Republic".

\section{Conflict of Interest}

None declared.

\section{REFERENCES}

1. Valkonen T. Life expectancy and adult mortality in industrialized countries. In: Smelser NJ, Baltes PB. International encyclopedia of the social and behavioral sciences. Amsterdam: Elsevier; 2001. p. 8822-7.

2. Meslé F, Vallin J. Mortality in Europe: the divergence between east and west. Population (English edition). 2002;57(1):157-97.

3. Meslé F. Mortality in Central and Eastern Europe: long-term trends and recent upturns. Demogr Res Spec Collect. 2004;(2):45-70. doi: 10.4054/ DemRes.2004.S2.3.

4. Hoffmann R. Socioeconomic differences in old age mortality. The Springer series on demographic methods and population analysis. Springer; 2013.

5. Myers GC. Comparative mortality trends among older persons in developed countries. In: Caselli G, Lopez AD, editors. Health and mortality among elderly populations. Oxford: Clarendon Press; 1996. p. 87-111.
6. Šprocha B. Mortality and ageing of Slovak population. Projection of future development in the context of the old-age pension system. Progn Pr [Internet]. 2013 [cited 2017 Dec 10];5(2):79-102. Available from: http://www. prog.sav.sk/fileadmin/pusav/download_files/prognosticke_prace/2013/ clanok_1_SprochaPP_5_2013_2.pdf.

7. Smith GD, Shipley MJ, Rose G. Magnitude and causes of socioeconomic differentials in mortality: further evidence from the Whitehall Study. J Epidemiol Community Health. 1990; 44(4):265-70.

8. Clarke P, Latham K. Life course health and socioeconomic profiles of Americans aging with disability. Disabil Health J. 2014;7:15-23.

9. Adler NE. Consideration of multiple pathways from socioeconomic status to health. In: Auerbach JA, Krimgold BK, editors. Income, socioeconomic status and health: exploring the relationship. Washington, DC: National Policy Association; 2001. p. 56-66.

10. Della Bella S, Sarti S, Lucchini M, Tognetti Bordogna M. A Comparative analysis of inequality in health across Europe. Sociol Res Online. 2011;16(4). doi: 10.5153/sro.2492.

11. Gavurová B, Šoltés V, Kafková K, Černý L'. Selected aspects of efficacy in the Slovak health service. One-day health care and its development in the Slovak Republic. Košice: Technical University of Košice; 2013. (In Slovak.)

12. Gavurová B, Vagašová T. Regional differences of standardised mortality rates for ischemic heart diseases in the Slovak Republic for the period 1996-2013 in the context of income inequality. Health Econ Rev. 2016;6:21. doi:10.1186/s13561-016-0099-1.

13. Murray CJL, Lopez AD, Black RE, Mathers CD, Shibuya K, Ezzati M, et al. Global burden of disease 2005: call for collaborators. Lancet. 2007;370(9582):109-10.

14. Mathers CD, Loncar D. Projections of global mortality and burden of disease from 2002 to 2030. PLoS Med. 2006;3(11):e442. doi: org/10.1371/ journal.pmed.0030442.

15. GBD 2013 Mortality and Causes of Death Collaborators. Global, regional, and national age-sex specifi c all-cause and cause-specifi c mortality for 240 causes of death, 1990-2013: a systematic analysis for the Global Burden of Disease Study 2013. Lancet. 2015 Jan 10;385(9963):117-71.

16. Ezzati M, Friedman AB, Kulkarni SC, Murray CJ. The reversal of fortunes: trends in county mortality and cross-county mortality disparities in the United States. PLoS Med. 2008 Apr 22;5(4):e66. doi: 10.1371/ journal.pmed.0050066.

17. Kibele EUB. Regional mortality differences in Germany. Dordrecht: Springer Science+Business Media; 2012.

18. Kvetan V, Páleník V, Mlýnek M, Radvanský M. Ageing, health status and determinants of health expenditure in Slovakia. Bratislava: Institute of Economic Research SAS; 2007. (In Slovak.)

19. Leyland AH, Dundas R, McLoone P, Boddy FA. Cause-specific inequalities in mortality in Scotland: two decades of change. A population-based study. BMC Public Health. 2007;7:172. doi: 10.1186/1471-2458-7-172.

20. Eurostat database. GDP at regional level [Internet]. [cited 2016 Jul 10]. Available from: http://ec.europa.eu/eurostat/statistics-explained/index. php/GDP_at_regional_level.

Received October 17, 2016 Accepted in revised form December 19, 2017 